\title{
Donata Romizi: Dem wissenschaftlichen Determinismus auf der Spur: Von der klassischen Mechanik zur Entstehung der Quantenphysik. Karl Alber: Freiburg/München 2019, 504 pp., $€ 69.00$ (hardcover), ISBN: 9783495491034
}

\section{Fynn Ole Engler ${ }^{1}$}

Published online: 6 June 2021

(C) The Author(s) 2021

In recent decades there have been many in-depth studies and intense debates on the close relationship between the various philosophical strands and the sciences on the threshold of the twentieth century, with particular reference to the profound and far-reaching conceptual and technological revolutions in modern physics. This has been accompanied by a renaissance of the philosophy of space-time from various historical and systematic perspectives. Against this background, new insights also opened up in the prospering fields of the history and philosophy of science and the philosophy of physics in particular. Nevertheless, in this context, with some exceptions, the origins and developments of scientific determinism, still receive very little attention. Donata Romizi, however, places this seemingly familiar concept at the center of her book and seeks to rethink supposedly fixed views on scientific determinism. $^{1}$

According to the standard historiography, scientific determinism has its origins in classical Newtonian physics and its associated natural philosophy, and reached its apogee in Laplace's idea of an omniscient intelligence that can with certainty fully predict the future of the physical world based on natural laws. With the advent of quantum mechanics in the 1920s, however, physics turned to scientific indeterminism.

Romizi, in her comprehensive study, which is divided into three parts, challenges this socalled received opinion. In the first part, she explains the concept of scientific determinism in terms of its firmness (mathematical, inductive, statistical), profundity or ontological commitment (fixed, pragmatic, normative, realist), and broadness (systems, laws, descriptions, worldview). Given this background, she argues that the complex and multi-layered history of the concept of scientific determinism had its starting point in the early modern period in the course of developing classical mechanics, which, in natural philosophy, was underpinned by a rationalist understanding of science as an axiomatic-deductive system. ${ }^{2}$ In this context,

1 See Earman (1983; 2004), Hacking (1983; 1990), Norton (2008), and Strien (2014a, b), for further details and discussion on scientific determinism.

2 For more on this topic, cf. Pulte (2005).

Fynn Ole Engler

oengler@mpiwg-berlin.mpg.de

1 Institute for Philosophy, University of Rostock, 18051 Rostock and Max Planck Institute for the History of Science, Boltzmannstraße 22, 14195 Berlin, Germany 
according to one of Romizi's central arguments, an "implicit scientific determinism" emerged that possessed a realistically interpreted mathematical-geometrical core defined by the works of Laplace and Leibniz and specified by universally valid laws and certain principles. These principles, in hindsight, shaped essentially the firm belief in scientific determinism until its explicit formulation in the wake of the development of analytical mechanics in the second half of the nineteenth century.

By this time, however, the concept of scientific determinism had also undergone a series of changes that led to its weakening, especially in Kant's transcendental philosophy and later, in the nineteenth century, through the rise of statistics in the course of the "probabilistic revolution", as Romizi demonstrates in the second part of her study, relying here on pertinent works (the relationship between Kant's philosophy and the exact sciences has been discussed in detail in Friedman 1992; the "probabilistic revolution" has been widely studied in Hacking 1975; Porter 1986; Krüger et al. 1987). Despite this significant weakening in terms of its profundity and firmness, an explicit formulation of determinism as a comprehensive worldview distinct from indeterminism occurred mainly in public lectures and popular scientific works with considerable social and political relevance. It is primarily this perspective, that focuses on the period from about 1860 to 1920, with which Romizi's study extends previous research by explicating the broad intellectual and ideological context of the debate between determinism and indeterminism, which became more and more accentuated in a society increasingly shaped by science and technology. In this regard, Romizi argues in the third part of her study, scientific determinism was often advocated or rejected as a substitute for other social and political issues that went far beyond the natural sciences and also involved ethical and religious beliefs.

Finally, against this background, Romizi considers again the tradition of the Vienna Indeterminism previously outlined in the works of Michael Stöltzner and Deborah Coen (Coen 2007; Stöltzner 1999; 2003). In doing so, she shifts the focus in particular to Edgar Zilsel, a Kantian, later member of the Vienna Circle, and convinced social democrat who studied at the Institute of Physics in Vienna from 1910 to 1915. As Romizi argues, Zilsel's approach to the question of determinism exhibits features similar to those of Franz Serafin Exner, one of the key figures of Vienna Indeterminism. Thus, Zilsel should also be considered a hitherto forgotten representative of this tradition.

As a whole, Romizi's study offers a systematically well-founded as well as historically informed treatise on the formation and long-term development of the concept of scientific determinism. Worthwhile is the study of her detailed and sophisticated analysis of the historical contexts, which provides a profound basis for the successful revision of the received view presented at the outset, which Romizi undoubtedly provides, but which also offers room for further investigation. For example, the concept of scientific determinism has been little studied in the period between Newton and the mid-nineteenth century; moreover, the debate between determinism and indeterminism could be placed in the context of the emergence of Darwin's theory of evolution, as Romizi notes in an outlook at the end of her study. However, the book is recommendable not only for historians of science, but in any case also for those interested in a broader perspective on the debate about (in)determinism in the philosophy of science and, in particular, its current references to quantum theory.

Funding Open Access funding enabled and organized by Projekt DEAL. 
Open Access This article is licensed under a Creative Commons Attribution 4.0 International License, which permits use, sharing, adaptation, distribution and reproduction in any medium or format, as long as you give appropriate credit to the original author(s) and the source, provide a link to the Creative Commons licence, and indicate if changes were made. The images or other third party material in this article are included in the article's Creative Commons licence, unless indicated otherwise in a credit line to the material. If material is not included in the article's Creative Commons licence and your intended use is not permitted by statutory regulation or exceeds the permitted use, you will need to obtain permission directly from the copyright holder. To view a copy of this licence, visit http://creativecommons.org/licenses/by/4.0/.

\section{References}

Coen, D. (2007). Vienna in the age of uncertainty. Science, liberalism, and private life. Chicago: University of Chicago Press.

Earman, J. (1983). A primer on determinism. Dordrecht: Reidel.

Earman, J. (2004). Determinism: What we have learned and what we still don't know. In J. K. Campbell, M. O'Rourke, \& D. Shier (Eds.), Freedom and determinism (pp. 21-46). Cambridge, MA: MIT Press.

Friedman, M. (1992). Kant and the exact sciences. Cambridge, MA: Harvard University Press.

Hacking, I. (1975). The emergence of probability. New York, NY: Cambridge University Press.

Hacking, I. (1983). Nineteenth century cracks in the concept of determinism. Journal of the History of Ideas, 44(3), 455-475.

Hacking, I. (1990). The taming of chance. Cambridge: Cambridge University Press.

Krüger, L., Daston, L., \& Heidelberger, M. (Eds.). (1987). The probabilistic revolution. (Vol. 1). MIT Press. Norton, J. (2008). The dome: An unexpectedly simple failure of determinism. Philosophy of Science, 75, $786-798$.

Porter, T. M. (1986). The rise of statistical thinking. 1820-1900. Princeton, NJ: Princeton University Press.

Pulte, H. (2005). Axiomatik und Empirie. Eine wissenschaftstheoriegeschichtliche Untersuchung zur Mathematischen Naturphilosophie von Newton bis Neumann. Darmstadt: WBG Wissenschaftliche Buchgesellschaft.

Stöltzner, M. (1999). Vienna indeterminism: Mach, Boltzmann, Exner. Synthese, 119, 85-111.

Stöltzner, M. (2003). Vienna indeterminism II. From Exner to Frank and von Mises. In P. Parrini, W. C. Salmon, \& M. H. Salmon (Eds.), Logical empiricism. Historical and contemporary perspectives (pp. 194-232). Pittsburgh, PA: University of Pittsburgh Press.

van Strien, M. (2014a). On the origins and foundations of Laplacian determinism. Studies in History and Philosophy of Science, 45(1), 24-31.

van Strien, M. (2014b). The Norton dome and the nineteenth century foundations of determinism. Journal for General Philosophy of Science, 45, 167-185.

Publisher's Note Springer Nature remains neutral with regard to jurisdictional claims in published maps and institutional affiliations. 